\title{
Efektivitas Literasi Bidang PAI Dalam Meningkatkan Minat Baca Siswa di SMP Sebelas Maret Pabuaran Bogor
}

\author{
Anis Nurhasanah ${ }^{1}$ Ariadi $^{2}$ Imah Rosidah $^{3}$ \\ ${ }^{1}$ Pendidikan Agama Islam, Sekolah Tinggi Agama Islam Fatahillah Serpong \\ Email : anisnh24@gmail.com \\ ${ }^{2}$ Pendidikan Agama Islam, TPQ Riyadhul Jannah \\ Email : ariadistaif@gmail.com \\ ${ }^{3}$ Pendidikan Agama Islam, Madrasah Ibtidaiyah Nuruh Huda Pengasinan Bogor \\ Email : imahrosyidah1002@gmail.com
}

\begin{abstract}
The objectives in this study are 1) Knowing the interests of reading students in Junior High School Eleven Maret Paburan, 2) Knowing the literacy program in the field of Islamic religious education 3) Knowing the obstacles faced in increasing the reading interest of students 4) Knowing the results of students' reading interests after the literacy program in the field of Islamic religious education. This research method uses qualitative types with phenomenological approaches. This research obtained the results namely 1) The interest in reading students in SMP Sebelas Maret Pabuaran is still classified as standard because several factors namely factors in and out of students 2) literacy program in the field of Islamic religious education in SMP Sebelas Maret Pabuaran is divided into two sections, namely reading non-textbooks for 15 minutes before learning and literacy of the Qur'an every Thursday and Saturday in the exculpation of reading the Qur'an an 3) the problems faced by teachers are the lack of collection of non-textbooks and the absence of librarians due to budget constraints 4) the reading interest of grade IX students after the pai field literacy program increased significantly judging by the raport value of students who initially only 60-70 currently increased to 80-90 data in the 2019/2020 school year.
\end{abstract}

Keywords : Literacy, PAl, Interests, Read

Abstrak. Tujuan dalam penelitian ini yaitu 1) Mengetahui minat baca siswa di SMP Sebelas Maret Paburan, 2) Mengetahui program literasi bidang pendidikan agama Islam 3) Mengetahui kendala-kendala yang dihadapi dalam meningkatkan minat baca siswa 4) Mengetahui hasil minat baca siswa setelah adanya program literasi bidang pendidikan agama Islam. Metode penelitian ini menggunakan jenis kualitatif dengan pendekatan fenomenologis. Penelitian ini mendapatkan hasil yaitu 1) Minat baca siswa di SMP Sebelas Maret Pabuaran masih tergolong standar dikarenakan beberapa faktor yaitu faktor dalam diri dan dari luar diri siswa 2) program literasi bidang pendidikan agama Islam di SMP Sebelas Maret Pabuaran terbagi menjadi dua bagian yaitu membaca buku non pelajaran selama 15 menit sebelum pembelajaran dan literasi Al-Qur'an setiap kamis dan sabtu masuk dalam ekskul baca Tulis Qur'an 3) kendala yang dihadapi guru yaitu kurang nya koleksi buku non pelajaran dan tidak adanya pustakawan karena keterbatasan anggaran 4) hasil minat baca siswa kelas IX setelah adanya program literasi bidang PAI meningkat signifikan dilihat dari nilai raport siswa yang awalnya hanya 6070 saat ini meningkat menjadi 80-90 data pada tahun ajaran 2019/2020.

Kata Kunci : Literasi, PAl, Minat, Baca

\section{PENDAHULUAN}

Penguasaan seorang individu atau peserta didik terhadap ilmu dimulai dengan membaca. Secara teoritis, bahwa terdapat hubungan positif antara kemampuan membaca (reading ability) dan kebiasaan membaca (reading habit) dengan minat baca (reading interest). Tinggi rendahnya minat 
baca masyarakat berhubungan dengan tinggi rendahnya kebiasaan membaca berpengaruh pula terhadap tingkat kemampuan membaca. Chasah, Uswatun. (2019)

Wahyu yang pertama kali diturunkan kepada Nabi Muhammad SAW, terdapat dalam AlQur'an surat Al-Alaq ayat satu sampai dengan ayat lima yang berbunyi :

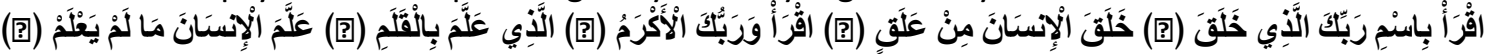

Bacalah dengan (menyebut) nama Tuhanmu yang menciptakan, Dia telah menciptakan manusia dari segumpal darah. Bacalah, dan Tuhanmulah Yang Maha Mulia. Yang mengajar manusia dengan pena. Dia mengajarkan manusia apa yang tidak diketahuinya.(Q.S.Al-Alaq ayat 1-5)

Yang mana tersurat dalam surat ini adalah perintah membaca. Perintah membaca merupakan perintah berharga yang diberikan kepada umat manusia. Sebab, membaca merupakan jalan yang dapat mengantar manusia sampai derajat kemanusiaan yang sempurna, sehingga tidak berlebihan jika dikatakan bahwa "membaca" adalah syarat utama guna membangun peradaban dan pengetahuan. Selain kegiatan membaca pesan yang tersurat dalam surat Al-Alaq ini juga sangat jelas bahwa keberadaan Islam memberi risalah mengajarkan manusia agar selalu membaca dan menulis sebagai sarana proses transformasi ilmu dan pengetahuan.

Keberhasilan sebuah pembelajaran dapat dipengaruhi beberapa komponen, antara lain guru, siswa, sumber belajar, tujuan pembelajaran, dan hasil pembelajaran. Begitu juga dengan pembelajaran pendidikan agama Islam, membutuhkan guru yang kompeten untuk menciptakan proses pembelajaran yang baik. Tidak hanya itu, sebuah pembelajaran perlu didukung dengan adanya sumber pembelajaran yang dapat menunjang keberhasilan belajar siswa dan juga sebuah kegiatan yang dapat mempermudah siswa dalam memahami dan mengikuti proses pembelajaran dengan baik.

Hal ini penting karena individu yang sudah memiliki kemampuan membaca tidak serta merta kemudian mau menggunakan keterampilannya itu dalam aktivitas sehari-hari. Dari sinilah budaya dan kebiasaan membaca menjadi fokus kedua dalam konsep literasi. Individu atau masyarakat yang memiliki tingkat literasi tinggi bukan semata ditentukan karena kemampuan dan minat membacanya saja, tetapi juga kebiasaan dan budaya membacanya, yaitu masyarakat yang secara aktif mengisi segala aktivitasnya dengan membaca karena membaca menjadi saluran utama dalam mengakses informasi dan ilmu pengetahuan. (Sarwiji Suwandi, 2019)

Dari penjelasan diatas, jelaslah bahwa aspek dasar literasi bersumber pada membaca yang terkait dengan kemampuan membaca, minat membaca, serta kebiasaan membaca setiap individu.

Pada era modern ini, kita mendapati banyak sekali persoalan dimana siswa kurang berminat dalam mempelajari Al-Qur'an dan cenderung lebih mementingkan pelajaran yang berbau umum dari pada keagamaan, sehingga kerap kali siswa lalai dari belajar agama. GLS merupakan suatu usaha atau kegiatan yang bersifat partisipatif dengan melibatkan warga sekolah (peserta didik, guru, kepala sekolah, tenaga kependidikan, pengawas sekolah, Komite Sekolah, orang tua/wali murid peserta didik), akademisi, penerbit, media massa, masyarakat (tokoh masyarakat yang dapat mempresentasikan keteladanan, dunia usaha, dan lain-lain), dan pemangku kepentingan di bawah koordinasi Direktorat Jenderal Pendidikan Dasar dan Menengah Kementrian Pendidikan dan Kebudayaan. (Nur Widyani, dkk, 2016)

Gerakan literasi sekolah yang berlaku sekarang ini masuk dalam Peraturan Menteri Pendidikan dan Kebudayaan Republik Indonesia Nomor 23 Tahun 2015 tentang penumbuhan budi pekerti, termasuk di dalamnya ada siswa diperbolehkan membaca buku apapun selama 15 menit (Peraturan Menteri Pendidikan dan Kebudayaan), yang kemudian dilanjutkan dengan kegiatan pendukung lainnya semacam literasi baris berbaris, literasi kebersihan, dan lainnya.

Berdasarkan pemaparan di atas maka peneliti tertarik untuk melakukan penelitian dengan judul Efektivitas Literasi dalam Meningkatkan Minat Baca Siswa di SMP Sebelas Maret Pabuaran Gunung Sindur Bogor. 


\section{METODE PENELITIAN}

Jenis penelitian yang digunakan dalam penelitian ini adalah kualitatif dengan pendekatan fenomenologis. Karakteristik dari penelitian kualitatif yang akan digunakan oleh peneliti adalah deskriptif, yaitu data yang dikumpulkan berupa kata-kata, gambar, dan bukan angka-angka dari hasil observasi yang kemungkinan akan menjadi sebuah kunci terhadap apa yang sudah diteliti. Jenis dari penelitian kali ini adalah menggunakan penelitian lapangan (field reaserch) yaitu dengan mengadakan penelitian dengan cara terjun langsung ke lapangan yang dijadikan sebagai subjek penelitian serta peneliti terlibat langsung didalamnya. (J.R.Racoo, 2010: 9)

Dalam penelitian ini sumber data yang peneliti gunakan yaitu sumber data primer dan sumber data sekunder, yang menjadi informan dalam penelitian ini adalah kepala sekolah yang juga bertugas sebagai guru PAI, Wakil kepala sekolah yang juga bertugas sebagai guru bahasa Indonesia, dan juga 5 orang siswa yang menjadi obyek wawancara. Sedangjan teknik pengumpulan data yang peneliti gunakan yaitu Observasi, Wawancara, dan Dokumentasi.

Setelah proses pengumpulan data (observasi, wawancara dan dokumentasi), dilakukan pengkodian dan dikelompokan. Dalam penelitian kualitatif data coding atau pengodean data memegang peranan penting dalam proses analisis data, dan menemukan kualitas abstraksi data hasil penelitian. Salah seorang soiologi bernama Anselm Strauss pernah mengatakan demikian. "Setiap peneliti yang berkeinginan untuk menjadi mahir dalam melakukan analisis kualitatif, harus belajar untuk mengodekan data dengan baik dan mudah. Keunggulan penelitian sebagian besar terletak pada keunggulan pengodean data." (Joseph Robert Daniel, 2020)

\section{HASIL PENELITIAN DAN PEMBAHASAN}

\section{Minat Baca Siswa di SMP Sebelas Maret Paburan}

Pada awalnya, membaca sering kali ditafsirkan sebagai hal yang sepele, atau sering dianggap remeh, namun pada kenyataannya membaca memiliki banyak sekali manfaat. Setelah mengetahui pentingnya membaca, oleh karena itu ketika siswa sedang membaca alangkah baiknya kita memberikan suasana yang tenang dan nyaman. Dengan keadaan yang tenang dan nyaman maka siswa akan merasa betah untuk tinggal lama di perpustakaan tanpa harus diminta. Hal ini sesuai dengan yang di ungkapkan oleh kepala sekolah yang mengatakan bahwa:

"Minat baca anak-anak itu sangat bervariasi ada anak yang memang senang membaca dan ada juga yang malas sekali untuk membaca, bahkan tidak jarang untuk berkunjung ke perpustakaan tanpa di minta pun jarang sekali. Namun ketika perpustakaan mulai di benahi kegiatan membaca di rutinkan, Alhamdulillah minat baca siswa meningkat, setiap hari selalu ada saja yang berkunjung ke perpustakaan tanpa di temani guru bidangnya. Mungkin mereka sudah merasa nyaman dengan kondisi perpustakaan yang rapi dan tertata." (W.3.a.01)

Ada berbagai macam faktor yang menyebabkan siswa sehingga malas untuk membaca. Teknologi yang ada saat ini mengganggu kegiatan belajar sebagian siswa, karena dengan keberadaan Handphone, televisi dan media elektronik lainnya waktu belajar pun ditinggalkan, demi mengikuti keinginan dirinya sendiri, sebagian siswa rela meninggalkan belajar demi apa yang mereka sukai. Selain beberapa faktor yang menyebabkan para siswa malas untuk membaca, karena dipengaruhi oleh beberapa faktor, diantaranya seperti lingkungan, kurangnya perhatian orang tua, dan keberadaan teknologi informasi yang semakin canggih.

Guru dan orang tua memiliki peranan yang sangat penting bagi kegiatan anak baik di sekolah maupun di rumah, guru dan orang tua tetap harus mengawasi aktivitas anak selama berada di lingkungan sekolah maupun lingkungan rumah, berbagai macam cara perlu dilakukan untuk dapat mengembangkan minat baca siswa apapun cara nya guru dan orang tua harus memikirkan untuk selalu 
bisa mengembangkan minat siswa dalam membaca, seperti halnya yang di ungkapkan oleh bapak Oos, yang mengatakan bahwa:

"Saya selaku guru dan yang menjaga perpustakaan berharap baik ketua yayasan, sekolah, guru dan pemerintah dapat membantu kami untuk bisa memberikan fasilitas dan kelengkapan perpustakaan karena memang sampe saat ini perpustakaan kami belum begitu banyak jumlah literaturnya, namun tidak menutup kemungkinan kami selalu berupaya untuk bisa mengembangkan minat anak dengan cara-cara sederhana namun membawa dampak yang besar bagi siswa." (W.3.c.03)

Perpustakaan menjadi sarana vital bagi sekolah terkait minat baca siswa, untuk mengetahui perkembangan mibat baca siswa perlu di lihat seberapa sering anak-anak berkunjung ke perpustakaan secara mandiri tanpa perintah dari guru bidang studi. Faktor dari dalam dirinya adalah siswa tidak dibiasakan membaca sejak dini sehingga tidak mempunyai kebiasaan untuk terus membaca, masih kurangnya pengetahuan tentang betapa pentingnya membaca, dan kurangnya minat yang tumbuh dalam dirinya sendiri. Faktor dari luar diri siswa adalah kurangnya perhatian orang tua terhadap aktivitas anak selama dirumah, tidak adanya buku penunjang nonpelajaran dirumah dan dibiarkan memilih sesuatu tentang apa yang anak sukai padahal belum tentu baik bagi dirinya, dorongan guru yang belum menguatkan betapa pentingnya membaca buku untuk mendapatkan informasi dari berbagai sumber yang relevan.

Literasi dianggap sebagai modal utama bagi siswa maupun generasi muda dalam belajar dan menghadapi tantangan-tantangan masa depan. Literasi pada awal kemunculannya dimaknai sebagai keberaksaraan atau melek aksara yang fokus utamanya pada kemampuan membaca dan menulis, dua keterampilan yang menjadi dasar untuk melek dalam berbagai hal. Namun selanjutnya, literasi dimaknai sebagai melek membaca, menulis dan numeric. Literasi juga merupakan tonggak kemajuan suatu bangsa. Literasi sangat perlu dipupuk agar generasi gemar membaca dan menulis. Apa lagi pada era digital ini, segala sesuatu membutuhkan kemampuan literasi. (Tri Endah Priyanti dan Nurhadi 2017).

\section{Mengetahui Program Literasi Bidang Pendidikan Agama Islam}

Salah satu bentuk kegiatan literasi yang ada di Indonesia adalah Gerakan Literasi Sekolah. Gerakan Literasi Sekolah ini bertujuan untuk meningkatkan minat baca siswa dan mengembangkan budi pekerti siswa. Melalui kegiatan literasi dapat meningktkan minat baca siswa dan juga menambah pengetahuan siswa, selain kegiatan iterasi membaca buku nonpelajaran, di SMP Sebelas Maret Pabuaran Gunung Sindur juga menerapkan kegiatan literasi Al-Qur'an sebelum pembelajaran di mulai setiap hari senin dan kamis. Kegiatan ini bertujuan untuk memperbaiki bacaan Al-Qur'an siswa, mengembangkan hafalannya, serta mengembangkan budi pekerti siswa. Dari kegiatan observasi, wawancara dan dokumentasi, peneliti menganalisis terkait permasalahan Efektivitas Literasi dalam Meningktkan Minat Baca Siswa di SMP Sebelas Maret Pabuaran Gunung Sindur Bogor.

Untuk mengetahui pelaksanaan program literasi dalam meningkatkan minat baca siswa kelas IX SMP Sebeas Maret Pabuaran Gunung Sindur Bogor, peneliti mengadakan wawancara dengan berbagai pihak yang terkait seperti kepala sekolah, guru PAI, Wakasek Kesiswaan/guru bahasa sunda dan siswa, observasi proses belajar mengajar PAI dan kegiatan literasi baik di dalam kelas saat pembelajaran tatap muka dan saat pembelajarang online dirumah siswa masing-masing.

Program literasi secara resmi sudah duterapkan di SMP Sbelas Maret Pabuaran Gunung Sindur Bogor pada 4 tahun yang lalu yaitu pada tahun 2016. Pada awalnya kegiatan membaca hanya berkisar buku mata pelajaran dan juga membaca ayat Al-Qur'an atau juz 'amma sebelum pembelajaran. Untuk literasi baca buku di kelas diterapkan awal tahun pelajaran 2017/2018 setelah keluarnya kebijakan kurikulum 2013. 
Berikut penuturan ibu Tsarwah Lubis terkait pelaksanaan program literasi di SMP Sebelas Maret Pabuaran Gunung Sindur Bogor yang mengungkapkan bahwa :

"Program literasi sudah kami terapkan semenjak adanya kurikulum 2013 namun pada saat itu hanya membaca buku materi pelajaran saja sebelum pembelajaran, namun setelah adanya peraturan Permendikbud No 23 Tahun 2015 kami baru menerapkan pembiasaan membaca buku nonpelajaran selam 15 menit di awal sebelum pembelajaran". (W.2.a.01).

Jadi program literasi di SMP Sebelas Maret Pabuaran Gunung Sindur Bogor sudah sejak tahun 2016 dan mulai diseriuskan dan mulai dikembangkan oleh pihak sekolah itu sejak tahun 2017, yaitu literasi membaca buku nonpelajaran setiap hari senin, selasa, rabu, dan kamis selama 15 menit sebelum dimulai pembelajaran. Berdasarkan hasil wawancara penelitti dengan ibu Tsarwah yang mengungkapkan sebagai berikut :

"Selain siswa membaca buku nonpelajaran, kami juga mengadakan literasi Al-Qur'an setiap hari jum'at dan masuk kedalam ekstrakulikuler setiap hari sabtu. Kegiatan EKSKUL BTQ ini diperuntukan bagi para siswa yang ingin mengembangkan kemampuan nya di bidang keagamaan dengan belajar menuliskaligrafi, bermain marawis, menulis Al-Qur'an dan juga menghafal surta-surat pendek" (W.2.f.01)

Dalam implementasi literasi pada pembelajaran pendidikan agama Islam biasanya guru memberikan tes membaca Al-Qur'an yang terdapat dalam buku Lembar Kerja Siswa (LKS) setiap materi yang disampaikan jika ada potongan ayat maka siswa diminta untuk membacakan potongan ayat di dalam buku pelajaran pendidikan agama Islam. Berdasarkan wawancara peneliti dengan kepala sekolah tentang implementasi literasi pada pembelajaran pendidikan Agama Islam beliau mengatakan bahwa :

"Biasanya anak-anak pada saat pembelajaran membuka LKS ada ayat-ayat Al-Qur'an nah disitu saya meminta siswa untuk membacakan ulang ayat yang ada di dalam buku, selain itu juga biasanya anak-anak saya minta untuk membaca LKS nya dan merangkum hasil bacaan setiap materi yang akan dipelajari." (W.2.f.01)

Guru berharap dengan menerapkan literasi kedalam setiap mata pelajaran akan menumbuhkan minat baca yang kuat pada asiswa, selain itu segala informasi bisa mereka dapatkan dengan membaca buku, mereka bisa berdiskusi dengan baik dan dapat memecahkan masalah dengan dewasa sesuai dengan kemampuan mereka.

Untuk mengetahui seberapa efektif implementasi program literasi yang diterapkan dalam pembelajaran PAI dapat diketahui pada saat proses pembelajaran berlangsung dilihat sejauh mana para siswa dapat mengerjakan tugas, memecahkan masalah, merangkum hasil bacaan, dan mengulang bacaan ayat Al-Qur'an yang terdapat pada LKS mereka masing-masing.

\section{Mengetahui Kendala-Kendala Yang Dihadapi Dalam Meningkatkan Minat Baca Siswa}

Banyak perpustakaan yang masih kurang fasilitas karena ketidaksanggupan dan kurangnya perhatian pihak pimpinan dan kesadaran sebagian gur-guru di sekolah yang berpengaruh kepada keinginan siswa untuk berkunjung ke perpustakaan.

Hal ini sesuai dengan yang di kemukakan oleh guru yang sekaligus mengelola perpustakaan yang mengatakan bahwa :

" Di perpustakaan ini fasilitasnya masih kurang memadai, terutama pada koleksi buku nonpelajaran dan ruang baca, sehingga menjadi salah satu faktor siswa jarang masuk untuk membaca di perpustakaan. Di perpustakaan hanya ada buku-bukupenunjang pelajaran yang tidak begitu banyak ditambah ruang baca nya hanya ada meja dan kursi 
seadanya untuk siswa saja yang ingin masuk untuk membaca di perpustakaan" (w.3.e.03).

Jumlah buku dan gedung atau ruangan merupakan sarana penting dalam penyelenggaraan perpustakaan untuk menarik minat baca siswa.

Berdasarkan hasil wawancara di atas dapat disimpulkan bahwa kendala-kendala sekolah dalam meningkatkan program literasi dalam meningkatkan minat baca siswa terletak pada kurangnya buku bacaan di luar buku pelajaran, dan tidak adanya pustakawan tetap yang mengontrol keluar masuknya siswa ke dalam perpustakaan sehingga menyulitkan guru untuk bisa mengevaluasi siswa mana yang sering berkunjung ke perpustakaan.

\section{Mengetahui Hasil Minat Baca Siswa Setelah Adanya Program Literasi Bidang Pendidikan Agama Islam}

Untuk mengetahui hasil dari program literasi bidang pendidikan Agama Islam dalam meningkatkan minat baca siswa maka peneliti mengadakan wawancara terhadap beberapa guru dan siswa yang sekiranya dapat memberikan informasi yang peneliti butuhkan.

Bentuk kegiatan literasi yang dapat meningkatkan proses belajar mengajar PAI siswa menurut ibu Tsarwah mengatakan bahwa :

"Kebetulan di SMP Sebelas Maret Pabuaran ini belum ada kegiatan literasi khusus untuk meningkatkan PBM PAI, namun kegiatan literasi hari jum'at dan sabtu juga bisa berperan untuk membantu lebih senang membaca dan aktif ketika proses pembelajaran, ada juga kegiatan literasi Al-Qur'an dengan metode TARSANA namun kegiatan ini hanya untuk menunjang ekstrakulikuler BTQ kegiatan ini tidak mandiri karena dipandu oleh guru lain. (W.4.a.01)

"Menurut saya gerakan literasi itu dapat meningkatkan minat baca kami, biar anak-anak lebih giat lagi membaca buku terutama tentang pendidikan agama Islam yang ada pada pembelajaran kami, Cuma menurut saya si itu perlu lebih dikembangin lagi supaya kegiatannya makin menarik aja, tapi , memang selama ini bagi saya pribadi jadi lebih seneng aja membaca ka." (W.4.b.04)

Dengan hasil wawancara di atas dapat kita ketahui bahwa adanya program literasi dapat meningkatkan minat baca siswa khusus nya pada bidang pendidikan agama Islam yang memang mayoritas penduduk di Pabuaran beragama Islam jadi penting bagi mereka mempelajari agama Islam. Ditambah dengan adanya kegiatan literasi Al-Qur'an dapat membuat anak lebih giat dan semangat untuk membaca ayat-ayat Allah SWT, karena AI-Qur'an menjadi pedoman hidup bagi umat Islam.

Kemampuan membaca termasuk keterampilan literasi perlu mendapatkan penekanan dalam kompetensi. Dalam hal ini maka diperlukan kompetensi, pemilihan materi dan distribusinya di sekolah dasar maupun sekolah menengah. Di SMP Sebelas Maret Pabuaran Gunung Sindur Bogor penerapan kegiatan literasi sudah diterapkan semaksimal mungkin. Hal ini terbuktl dengan adanya sosialisasi secara berkala oleh pihak sekolah, guru yang menerapkan kegiatan literasi secara langsung dalam kegiatan pembelajaran, dan adanya kerjasama yang baik antara guru dan peserta didik.

Susanto menyatakan bahwa, perkembangan minat sangat tergantung pada lingkungan dan orang-orang dewasa yang akan berpegaruh pula terhadap kematangan psikologinya. (Amad Susantto, 2013:116). Di SMP Sebelas Maret Pabuaran dorongan untuk menummbuhkan minat membaca sudah diterapkan, terlihat ketika siswa mulai aitf saat pembelajaran berlangsung, berani mengungkapkan pendapat, dan mulai sering bertanya kepada guru pada saat proses KBM. Pendapat di atas sepandan dengan kegiatan literasi bidang pendidikan agama Islam dalam meningkatkan minat baca siswa di SMP Sebelas Maret Pabuaran Gunung Sindur Bogor. SMP Sebelas Maret Pabuaran berupaya untuk meningkatkan minat membaca siswa dengan membuat program-program literasi agar minat baca 
siswa meningkat, dan siswa merasa senang dengan adanya program-program yang di terapkan oleh guru sehingga mencapai keefektivan program literasi itu sendiri.

Setelah data diketahui sebagaimana yang peneliti sajikan pada fakta-fakta temuan peneliti di atas. Kemudian dilakukan reduksi data dengan menghilangkan data-ata yang tidak diperlukan. Maka sebagai tindak lanjut dari penelitian ini yaitu menganalisis data-data terkumpul dengan menggunakan deskriptif kualitatif dengan penekatan fenomenologis yaitu menerangkan keadaan dengan menggunakan kata-kata secara terperinci.

Literasi hadir sebagai tanggapan terhadap lahirnya dorongan masyarakat agar terjadi perubahan signifikan dalam dunia pendidikan, terutama terkait dengan dekadensi moral yang merebak dikalangan siswa saat ini. Mengenai literasi, kata ini diserap dari bahasa latin Literatus yang memiliki arti orang yang belajar (a learned person). Oleh sebab itu, seseorang yang dapat memiliki kemampuan membaca, menulis dan berbicara dalam bahasa Latin dikenal dengan istilah literatus. Literasi atau pengaksaraan merupakan kemampuan seseorang dalam menginterpretasi bacaan dan memproduksi tulisan. Dalam Standar Nasional Perpustakaan (NSP) menyatakan bahwa literasi adalah kemampuan untuk mengenal kebutuhan informasi untuk memecahkan masalah, mengembangkan gagasan, mengajukan pertanyaan penting, menggunakan berbagai strategi pengumpulan informasi, menetapkan informasi yang relevan, cocok dan otentik. (Krestiyani dkk'2011:12)

Dari defininisi ini menunjukkan bahwa literasi dimaksudkan untuk menjawab kebutuhan informasi dalam rangka memecahkan masalah sehingga literasi menjadi kebutuhan setiap orang. Sehubungan dengan kebijakan Kemendikbud tentang penumbuhan budi pekerti melalui program Gerakan Literasi Sekolah (GLS), SMP Sebelas Maret Pabuaran Gunung Sindur Bogor juga menerapkan kegiatan literasi sejak tahun 2017/2018. Berdasarkan fakta temuan di lapangan, kegiatan literasi di SMP Sebelas Maret Pabuaran Gunung Sindur Bogor terdapat dua bentuk pelaksanaannya, yaitu literasi buku nonpelajaran dan kegiatan literasi Al-Qur'an atau membaca Al-Qur'an

Literasi Al-Qur'an atau kegiatan membaca Al-Qur'an merupakan pengembangan dari kegiatan Gerakan Literasi Sekolah (GLS). Jika dalam GLS hanya menghimbau untuk membaca buku bacaan, tetapi di SMP Sebelas Maret Pabuaran Gunung Sindur Bogor mengembangkan kegiatan tersebut dengan kegiatan membaca Al-Qur'an pada awal pembelajaran. Kegiatan ini bertujuan untuk memperbaiki akhlak siswa, dan mengembangkan kemampuan membaca Al-Qur'an siswa mengingat ragam siswa yang ada di sekolah tersebut. Dalam mencapai tujuan dari materi pendidikan agama Islam tersebut, dibutuhkan sosok guru PAI yang bisa memberikan internalisasi nilai agama dengan cara memberi penyuluhan dan pemahaman tentang ajaran agama Islam secara utuh khususnya dalam literasi Al-Qur'an siswa, dilanjutkan dengan menyadarkan para siswa tentang bagaimana pentingnya literasi Al-Qur'an dengan penerapannya dalam kehidupan sehari-hari.

Selama kegiatan literasi bidang pendidikan agama Islam guru menemukan beberapa hambatan dalam meningkatkan minat baca siswa hambatan tersebut anytara lain:

a. Kedisiplinan siswa yaitu ketika jadwal membaca buku nonpelajaran atau membaca aAl-Qur'an masih ada siswa yang belum mempersiapkan buku atau Al-Qur'an dan atau juz 'amma nya.

b. Kesadaran membiasaan dir yang masih kurang jika tidak didampingi oleh guru.

c. Minat siswa yang cenderung naik turun yang sulit untuk di prediksi bagi guru.

d. Koleksi buku di dalam perpustakaan masih tergolong sedikit.

Adapun segala upaya untuk meningkatkan minat baca siswa selalu di evaluasi oeh para guru, adapun evaluasi atau upaya yang dilakukan oleh guru antara lain:

a. Pihak sekolah selalu memberikan motivasi, sosialisasi, dan pengertian mengenai kegiatan literasi kepada guru maupun siswa.

b. Pihak sekolah secara berkala mendiskusikan upaya atau metode yang diterapkan dalam pelaksanaan kegiatan literasi agar minat membaca siswa terus meningkat.

c. Pihak sekolah mengenalkan kepada siswa mengenai pentingnya menumbuhkan membaca dan budi pekerti.

d. Pihak-pihak sekolah berupaya mengadakan lomba sebagai salah wadah siswa untuk berpartisipasi aktif dalam kegiatan membaca. 
Dengan berbagai bentuk kegiatan dan upaya guru demi meningkatnya minat baca siswa di SMP Sebelas Maret berbagai upaya telah ditempuh oleh kepala sekolah dan guru bidang studi. Melalui kegiatan literasi bidang pendidikan agama Islam dengan melakukan pembiasaan membaca buku non pelajaran selama 15 menit, dan juga literasi Al-Qur'an yang dilaksanakan setiap hari jum;at dan sabtu termasuk juga kedalam ekskul sekolah minat baca siswa perlahan meningkat. Hal ini diketahui dengan hasil nilai raport siswa yang signifikan pada tahun ajaran 2019/2020 dari yang awalnya hanya mendapatkan nilai 60-70 saja kini sudah mencapai ke angka 80-90 setiap siswa. Hal ini membuktikan bahwa program litreasi sekolah di SMP Sebelas Maret Pabuaran sudah berjalan sebagaimana mestinya.

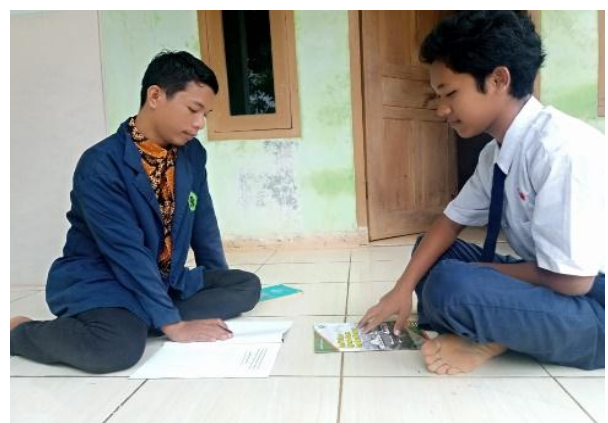

Gambar 1.1 Wawancara dengan Siswa

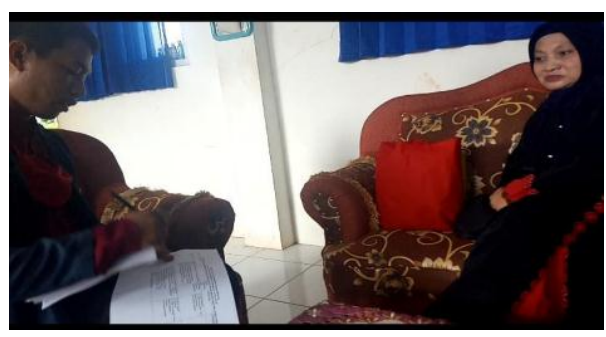

Gambar 1.2 Wawancara dengan Kepala Sekolah Sekaligus Guru PAI

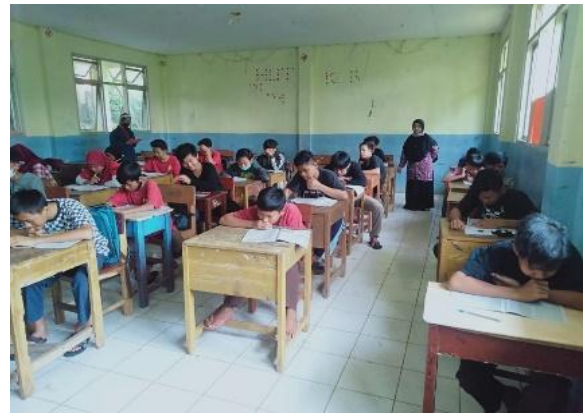

Gambar 1.3 Observasi Sekolah

\section{KESIMPULAN}

Berdasarkan hasil penelitian yang penulis lakukan dengan metode penelitian yang telah ditentukan dan berdasarkan hasil yang sebagaimana telah diuraikan dalam bab sebelumnya, maka dapat disimpulkan bahwa:

1. Minat baca siswa di SMP Sebelas Maret Pabuaran Gunung Sindur Bogor sebelumnya masih seperti biasa belum terlihat bahwa anak-anak suka membaca karena kegiatan literasi biang PAI masih beradaptasi dengan para siswa. 
2. Program Literasi bidang pendidikan agama Islam di SMP Sebelas Maret Pabuaran Gunung sindur Bogor, terbagi menjadi dua bagian yaitu literasi membaca buku non pelajaran di dalam kelas sebelum pembelajaran selama 15 menit. Kemudian literasi Al-Qur'an yakni, kegiatan membaca AlQur'an yang dilakukan sebelum pembelajaran setiap hari jum'at dan sabtu.

3. Kendala-kendala yang dihadapi oleh guru yaitu kurangnya koleksi buku pelajaran, dan tidak adanya pustakawan untuk mengontrol keluar masuknya siswa keperpustakaan.

4. Hasil program literasi bidang pendidikan Agama Islam di SMP Sebelas Maret Pabuaran Gunung Sindur. Upaya pihak sekolah untuk meningkatkan minat membaca kelas IX melalui kegiatan literasi adalah pihak sekolah selalu memberikan sosialisasi mengenai kegiatan literasi kepada guru maupun siswa, secara berkala mendiskusikan upaya atau metode yang diterapkan dalam pelaksanaan kegiatan literasi agar minat membaca meningkat mengenalkan pentingnya menumbuhkan minat dan budi pekerti yang luhur dengan mengadakan lomba-lomba sebagai wadah siswa untuk berpartisipasi aktif.

\section{DAFTAR PUSTAKA}

Amad Susantto, Teori Belajar dan Pembelajaran di Sekolah Dasar. Jakarta: Kencana Prenada Media Group, 2013, hal. 116

Chasah, Uswatun. (2019) Pengaruh Pasukan Literasi Terhadap Minat Baca Siswa SMPN 5 Surabaya, dalam Skripsi UIN Sunan Ampel Surabaya.: 2.

Daniel, Robert, Joseph, Coding: Sebuah Proses Penting dalam PenelitianKualitatif,dalam, http://josephrdaniel.wordpress.com/2013/08/16/coding-sebuahproses-penting-dalam-penelitian-kualitatif//, diakses pada 21 Juli 2020, Pkl: 16.57 WIB

Krestiyani dkk. (2011) Perpustakaan Nasional, Standar Nasional Perpustakaan. Jakarta: Perpustakaan Nasional. 12

Racco. J.R. (2010) Metode Penelitian Kualitatif, Jenis, Karakteristik, dan Keunggulannya. Jakarta: Grasindo. 9

Suwandi, Sarwiji, (2019) Penddiikan Literasi. Bandung: PT. Remaja Rosdakarya.:4-3.

Susanto, Amad. (2013).Teori Belajar dan Pembelajaran di Sekolah Dasar. Jakarta: Kencana Prenada Media Group. 116

Peraturan Menteri Pendidikan dan Kebudayaan, Penumbuhan Budi Pekerti. Diunduh dari simpuh.kemenag.go.id pdf. Diakses pada tanggal 26 Juli 2020 pukul 15.00

Priyanti, Endah, Tri dan Nurhadi. (2017) Membaca Kritis dan Literasi Kritis . Tangerang: Tira Smart. 157 Widyani, Nur, dkk. (2016). Panduan Gerakan Literasi Sekolah di SMK. Jakarta: Direktorat Jenderal Pendidikan Dasar dan Menengah Kementrian Pendidikan dan Kebudayaan. 7-8 